\title{
Proses Pembelajaran Matematika pada masa Covid-19 di MAN 2 Langkat
}

\author{
1)Faisal, 2)Dwi Santika Imron \\ 1)Dosen Pendidikan Matematika Institut Agama Islam Negeri Langsa \\ 2)Mahasiswa Pendidikan Matematika Institut Agama Islam Negeri Langsa \\ E-mail:faisal@iainlangsa.ac.id
}

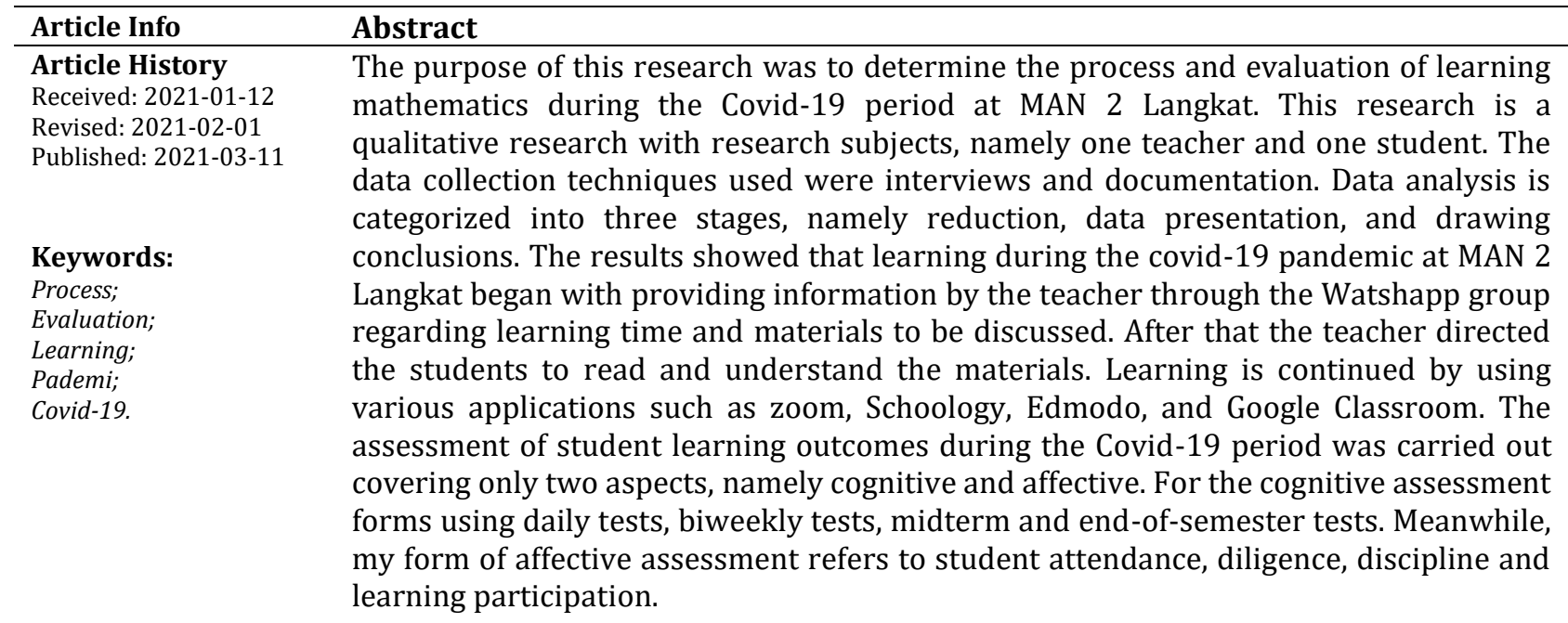

\begin{tabular}{l}
\hline Artikel Info \\
\hline Sejarah Artikel \\
Diterima: $2021-01-12$ \\
Direvisi: $2021-02-01$ \\
Dipublikasi: 2021-03-11
\end{tabular}

Kata kunci:

Proses;

Evaluasi;

Pembelajaran;

Pademi;

Covid-19.

\begin{abstract}
Abstrak
Tujuan penilitian ini adalah untuk mengetahui proses dan evaluasi pembelajaran matematika masa covid-19 di MAN 2 Langkat. Penelitian merupakan penelitian kualitatif dengan subjek penelitian yaitu satu orang guru dan satu orang siswa. Teknik pengumpulan data yang digunakan adalah, wawancara dan dokumentasi. Analisis data dikategorikan ke dalam tiga tahapan yaitu reduksi, penyajian data, dan penarikan kesimpulan. Hasil penelitian menunjukkan bahwa Pembelajaran pada masa pandemi covid-19 di MAN 2 Langkat, dimulai dengan Pemberian informasi oleh guru melalui grup Watshap mengenai waktu belajar dan materi yang akan dibahas. Setelah itu guru mengarahkan siswa untuk membaca dan memahami materi tersebut. Pembelajaran di lanjutkan dengan menggunakan berbagai aplikasi seperti zoom, Schoology, Edmodo, dan Google Classroom. Penilaian hasil belajar siswa pada masa covid-19 dilakukan meliputi dua aspek saja, yaitu kognitif dan afektif. Untuk bentuk penilaian kognitif menggunakan tes harian, tes dua mingguan, tes tengah semester dan tes akhir semester. Sedangkan bentuk penilaian afektif saya beracuan kepada kehadiran siswa, kerajinan, kedisiplinan serta partisipasi pembelajaran.
\end{abstract}

\section{PENDAHULUAN}

Proses Pembelajaran, Evaluasi Pembelajaran, MasaPendidikan merupakan suatu proses yang sangat penting dalam pembetukan sikap dan kepribadian seseorang. Pendidikan juga sangat berperan dalam pecapaian tujuan pembangunan suatu bangsa. Menurut Undang- Undang No. 20 Tahun 2003 Pasal 3 tentang Sistem Pendidikan Nasional menyatakan bahwa: Pendidikan nasional berfungsi mengembangkan kemampuan dan membentuk watak serta peradaban bangsa yang bermartabat dalam rangka mencerdaskan kehidupan bangsa, bertujuan untuk berkembangnya potensi siswa agar menjadi manusia yang beriman dan bertakwa kepada Tuhan Yang Maha Esa, berakhlak mulia, sehat, berilmu, cakap, kreatif, mandiri, dan menjadi warga negara yang demokratis serta bertanggung jawab.

Penyelengaraan pendidikan yang baik akan berpengaruh positif terhadap kemajuan peradaban suatu bangsa. Oleh karena itu fungsi pendidikan sangat penting bagi pribadi, keluarga dan masyarakat. Pendidikan sebagai proses atau upaya untuk memanusiakan manusia pada dasarnya adalah upaya mengembangkan kemampuan potensi individu sehingga memiliki kemampuan hidup optimal, baik sebagai pribadi maupun sebagai anggota masyarakat 
serta memiliki nilai-nilai moral religius dan sosial sebagai pedoman hidupnya.

Untuk mewujudkan tujuan pendidikan nasional dalam menyelesaikan perubahan-perubahan di bidang pendidikan, maka salah satu cara untuk mengatasi problematika tersebut adalah dengan memperbaiki pelaksanaan pembelajaran, yaitu dengan berbagai cara dan usaha yang mampu mengatasi kesulitan guru serta kesulitan siswa dalam mengikuti proses pembelajaran di kelas. Salah satu mata pelajaran yang sering dijadikan alasan tentang kesulitan belajar bagi kebanyakan siswa dalam proses pembelajaran adalah mata pelajaran matematika. Banyak siswa masih beranggapan matematika sebagai mata pelajaran yang sangat rumit, mempunyai banyak rumus serta tidak memiliki pengaruh yang besar dalam kehidupan mereka sehari-hari. Padahal matematika adalah salah satu mata pelajaran pokok yang mulai diajarkan dalam pendidikan formal mulai dari tingkat dasar sampai tingkat tinggi.

Matematika itu sendiri merupakan sebuah ilmu yang selalu berhubungan dengan kehidupan seharihari siswa. Kegiatan apapun yang siswa lakukan dalam kesehariannya tentunya akan berhubungan dengan ilmu matematika. Matematika dapat membekali siswa untuk memiliki kemampuan berpikir logis, analitis, sistematis, kritis dan kreatif, serta kemampuan bekerja sama (Sujono, 2018: 1). Kemampuan yang diberikan melalui pelajaran matematika sebagaimana yang tercantum dalam fungsi pendidikan nasional yang berdasarkan UndangUndang Dasar Negara Republik Indonesia Tahun 1945 yaitu mengembangkan kemampuan dan membentuk watak serta peradaban bangsa yang bermartabat dalam rangka mencerdaskan kehidupan bangsa.

Matematika merupakan mata pelajaran yang diajarkan di berbagai jenjang pendidikan. Pada mata pelajaran matematika, di mana kebanyakan kontennya bersifat abstrak, tidak sedikit siswa yang merasa kesulitan dalam mempelajarinya. Hal ini harus mendapat perhatian khusus dari beberapa pihak, seperti guru, lingkungan sekolah, wali siswa, dan lingkungan sekitar karena mata pelajaran matematika merupakan salah satu mata pelajaran wajib yang harus dipelajari oleh semua jenjang pendidikan dasar dan menengah termasuk Madrasah Tsanawiyah.

Hal ini selaras dengan tujuan pembelajaran matematika yang tertuang pada Permendikbud Nomor 22 Tahun 2016 yang menjelaskan tentang tujuan pembelajaran matematika diajarkan di sekolah agar siswa memiliki kemampuan sebagai berikut di antaranya: (1) Siswa dapat memahami konsep matematika, menjelaskan keterkaitan antarkonsep dan mengaplikasikan konsep/algoritma, secara luwes, akurat, efisien, dan tepat dalam pemecahan masalah; (2) Menggunakan penalaran pada pola dan sifat, melakukan manipulasi matematika dalam membuat generalisasi, menyusun bukti, atau menjelaskan gagasan dan pernyataan matematika; (3) Memecahkan masalah yang meliputi kemampuan memahami masalah, merancang model matematika, menyelesaikan model dan menafsirkan solusi yang diperoleh; (4) Mengomunikasikan gagasan dengan simbol, tabel, diagram, atau media lain untuk memperjelas keadaan atau masalah; (5) Memiliki sikap menghargai kegunaan matematika dalam kehidupan, yaitu memiliki rasa ingin tahu, perhatian, dan minat dalam mempelajari matematika, serta sikap ulet dan percaya diri dalam pemecahan masalah.

Guru sebagai tenaga profesional dibidang kependidikan, di samping memiliki pemahamanan tentang hal-hal yang bersifat filosofis dan konseptual, harus juga mengetahui dan melaksanakan hal-hal yang bersifat teknis. Hal-hal yang bersifat teknis ini, terutama kegaiatan mengelola interaksi belajar mengajar, guru paling tidak harus memiliki dua modal dasar, yakni kemampuan mendisain program dan keterampilan mengkomunikasikan program itu kepada anak didik.

Pada 31 Desember 2019 muncul kasus serupa dengan pneumonia yang tidak diketahui di Wuhan, China. Kasus tersebut di akibatkan oleh virus corona atau yang dikenal dengan COVID-19 (Corona Virus Desese-2019). Karakteristik virus ini adalah kecepatan penyebaran yang tinggi. Berdasarkan data WHO diperoleh bahwa COVID-19 telah menjadi pandemic global dengan 4.534.0731 kasus positif yang terkonfirmasi di 216 negara di seluruh dunia. Virus Corona juga telah mewabah di Indonesia sejak awal Maret hingga saat ini 12 Mei 2020 terdapat 17.514 kasus positif terkonfimasi tersebar di 34 provinsi dan 415 kabupaten/kota (Gugus Tugas Percepatan Penanganan COVID-19 Indonesia, 2020). Dampak yang ditimbulkan dari pandemi COVID-19 telah mengubah berbagai aspek kehidupan manusia (Luh Devi H, 2020: Vol 22 No.1).

Kisah wabah ini dapat memiliki akhiran yang berbeda pada setiap negara yang bergantung pada kebijakan yang diterapkan dan ketanggapan pemerintah guna meminimalisir penyebarannya. Untuk Indonesia sendiri, berbagai kebijakan telah dikeluarkan oleh pemerintah untuk mengurangi tingkat penyebaran virus corona dengan memberlakukan sosial distancing, physical distancing hingga pemberlakuan PSBB (pembatasan social berskala besar) pada beberapa daerah. Kebijakankebijakan yang dikeluarkan untuk membatasi penyebaran COVID-19 berdampak pada berbagai bidang diseluruh dunia khususnya pendidikan di Indonesia (Lee, A, 2020)

Wabah COVID-19 mendesak pengujian pendidikan jarak jauh hampir yang belum pernah dilakukan secara serempak sebelumnya bagi semua elemen pendidikan yakni peserta didik, guru hingga orang tua. Mengingat pada masa pandemic, waktu, lokasi dan jarak menjadi permasalahan besar saat ini Sehingga pembelajaran jarak jauh menjadi solusi untuk mengatasi kesulitan dalam melaksanakan pembelajaran secara tatap muka langsung. Ini memberikan tantangan kepada semua elemen dan jenjang pendidikan untuk mempertahankan kelas tetap aktif meskipun sekolah telah ditutup. 
Berdasatkan latar belakang di atas, maka diharapkan penelitian yang berjudul "Pembelajaran Matematika pada Masa Covid-19 di MAN 2 Langkat" ini dapat bermanfaat dalam menyikapi masa pandemi seperti masa pandemic Covid-19 saat ini.

\section{METODE PELAKSANAAN}

Penelitian ini dilaksanakan dengan menggunakan pendekatan kualitatif, alasan menggunakan pendekatan ini karena didasarkan pada pendeskripsian perilaku aktor-aktor yaitu kepala sekolah, guru matematika dan siswa/siswi sesuai dengan situasi yang ada di lapangan. Menurut Sugiyono, penelitian kualitatif adalah metode penelitian yang berlandaskan pada filsafat postpositivisme digunakan untuk meneliti pada kondisi obyek yang alamiah (sebagai lawannya adalah eksperimen) dimana peneliti adalah sebagai instrument kunci, teknik pengumpulan data dilakukan secara triangulasi (gabungan), analisis data bersifat induktif/kualitatif, dan hasil penelitian kualitatif lebih menekankan makna daripada generalisasi (Sugiyono, 2016: 9), sedangkan Teknik Penguumpulan data dalam penelitian ini adalah wawancara dan dokumentasi. sedangkan data dianalisis dengan cara reduksi data, kalrifikasi data dan penarikan kesimupulan.

\section{HASIL DAN PEMBAHASAN}

\section{A. Hasil Penelitian}

\section{Proses Pembelajaran}

Hasil penelitian menunjukkan bahwa pembelajaran yang dilaksanakan di MAN 2 Langkat semenjak adanya virus COVID-19 adalah sistem pembelajaran secara online. Menurut sebagian besar siswa sistem pembelajaran online yang diterapkan disekolah sudah efektif. Kegiatan pembelajaran online berjalan dengan baik dan menyenangkan meskipun terdapat suatu kendala dalam menggunakan aplikasi Zoom yaitu situasi koneksi internetnya lamban akibat kondisi wilayah tempat tinggal masing-masing siswa, akan tetapi apabila terjadi informasi yang kurang jelas guru akan mengulang penjelasannya hingga siswa memahami materi yang diberikan guru. Aplikasi yang digunakan untuk mata pelajaran yang diambilnya menggunakan Schoology, Google Classroom, dan Zoom.

Berikut hasil wawancara peneliti dengan Ibu SJ selaku guru Matematika di MAN 2 Langkat pada hari Jum'at tanggal 28 Agustus 2020 pukul 09.00 WIB di ruang guru mengenai persiapan sebelum mengajar Matematika sebagai berikut:

P: Apa saja yang ibu lakukan dalam upaya meningkatkan prestasi belajar siswa selama Covid-19 di MAN 2 Langkat?

J: Berbagai cara sudah kami lakukan agar para siswa memahami materi yang kami ajarkan meski melalui daring tidak dengan tatap muka. Salah satunya kami menyempatkan waktu untuk mengajar tatap muka di luar sekolah
P: Apa saja persiapan yang ibu lakukan sebelum mengajar selama Covid-19 di MAN 2 Langkat?

J: Setiap awal pembelajaran sebelum memulai pembelajaran, kami para guru biasanya mencari beberapa mengajarkan materi yang padat diwaktu yang singkat namun para siswa bisa paham apa yang diajarkan. Lalu para guru memberikan soal untuk bahan yang dipelajari siswa. Dari hasil jawaban mereka guru melihat paham tidaknya siswa terhadap materi yang diajarkan

P: Bagaimana pelaksanaan pembelajaran matematika di kelas selama Covid-19 di MAN 2 Langkat?

J: Dalam menyampaikan materi pembelajaran saya melakukannya secara terstruktur, dimulai dari menerangkan materi, kemudian memberikan contoh tiap point materi yang saya berikan latihan soal. Namun ini saya lakukan melalui daring dan door to door

P: Apakah Ibu pernah mengunjungi setiap rumah untukmelakukan pembelajaran selama Covid19 di MAN 2 Langkat?

J: Pernah saya dan guru matematika yang lain melakukan pembelajaran kerumah siswa atau sering disebut door to door. Setiap daerah saya menentukan satu rumah siswa untuk tempat mereka berkumpul belajar secara door to door.

P: Apakah ibu sering melakukan pembelajaran daring selama Covid-19 di MAN 2 Langkat?

J: Ya, saya memang mengajar secara daring setiap jam pelajaran matematika baik di kelas VII dan VIII. Hanya seminggu sekali saya melakukan door to door.

P: Strategi atau metode pembelajaran apa yang biasa ibu pakai dalam mengajar selama Covid19 di MAN 2 Langkat?

J: Saya menggunakan metode pembelajaran yang bervariasi. Beberapa metode yang saya gunakan adalah metode ceramah, metode Tanya jawab, metode diskusi, dan persentasi.

P: Bagaimana sistem evaluasi mata pelajaran Matematika selama Covid-19 di MAN 2 Langkat?

J: Setiap awal pembelajaran sebelum memulai pembelajaran, kami para guru biasanya mencari beberapa cara mengajarkan materi seperti program tahunan, program semester, silabus serta RPP. Dan untuk silabus serta RPP saya membuatnya secara personal dengan mengacu kepada panduan pembuatan RPP serta melihat beberapa RPP terdahulu yang digunakan pada MAN 2 Langkat. 
P: Apakah ada penambahan jam pelajaran Matematika selama Covid-19 di MAN 2 Langkat?

J: Disekolah tidak ada aturan yang mewajibkan tambah jam pelajaran untuk pelajaran matematika atau yang lainnya. Pelajaran berjalan sesuai jam pelajaran biasa yang telah terjadwal.

P: Apakah ada perbedaan yang menurut ibu terlihat mencolok antara belajar masa covi-19 di MAN 2 Langkat?

J: Kalau ditanya perbedaan saat belajar pada masa covid-19 dengan masa normal sangat banyak perbedaan. Terlihat jelas siswa sangat sulit memahami materi yang diajarkan

P: Apa saja kendala-kendala yang dihadapi dalam pembelajaran selama Covid-19 di MAN 2 Langkat?

J: Dalam proses pembelajaran matematika pada masa covid-19 sangat banyak kendala-kendala yang terjadi karena terbatasnya tatap muka yang terjadi antara guru dengan siswa salah satunya saat pengumpulan tugas siswa yang akan dinilai guru.

P: Bagaimana solusi yang ibu lakukan dalam mengatasi kendala tersebut selama Covid-19 di MAN 2 Langkat?

J: Anjuran dari sekolah solusi untuk mengatasi kendala yang terjadi pada masa covid-19 ini adalah mengajar dengan door to door

Dari segi pandang guru berpendapat bahwa pembelajaran ini telah beliau siapkan sejak awal sekolah untuk pelaksanaan belajar yang diajarkannya. Jadi tidak masalah apabila sekolah memberlakukan sistem pembelajaran online. Aplikasi yang digunakan dalam kegiatan pembelajaran yaitu Edmodo dan Zoom. Beliau tidak sama sekali mengalami kendala dalam kegiatan pembelajaran online, namun letak kendala terdapat pada siswanya yaitu masalah signal dan kendala kuota. Dalam kegiatan pembelajaran online beberapa guru lainnya menggunakan aplikasi seperti Google Classroom, dan Schoology sebagai tempat untuk mengirim materi.

Hasil pendapat guru di atas menunjukkan bahwa pada masa pandemi COVID-19 kegiatan pembelajaran online di MAN 2 Langkat oleh guru pada mata pelajaran matematika sudah efektif. Begitu juga pandangan siswayang berpendapat bahwa pembelajaran online yang dilaksanakan di MAN 2 Langkat sudah efektif karena banyak guru yang memberikan sistem pembelajaran online yang berbeda-beda seperti Zoom, Schoology, Google Classroom dan berbagai jenis aplikasi lainnya, hanya saja kendala yang disampaikan siswa yaitu masalah signal yang belum begitu bauik dan stabil. Berikut hasil wawancara dengan salah satu siswa MAN 2 Langkat:

P: Bagaimana persiapan guru Matematika sebelum mengajar online di MAN 2 Langkat?

J: Sebelum masuk jam pelajaran matematika, guru memberi tahu digrub yang sudah ada kapan pelajaran matematika akan dimulai. Lalu guru member mukaddimah dan sedikit materi diawal pembelajaran

P: Model, strategi dan metode pembelajaran online apa yang digunakan di MAN 2 Langkat?

J: Selama pelajaran matematika berlangsung yang sering saya liat guru menggunakan metode ceramah, diskusi dan Tanya jawab sama seperti ketika tatap muka

P: Apa evaluasi pembelajaran matematika dengan pembelajaran online di MAN 2 Langkat?

J: Evaluasi yang sering dilihat dari segi kognitif, efektif, dan psikomotorik. Semua penilaian ini dilihat dari artinya siswa selama pelajaran berlangsung dan soal-soal yang siswa kerjakan.

P: Apa saja kesulitan atau kendala saat mengajar Matematika pembelajaran online di MAN 2 Langkat?

J: Kendala yang siswa hadapi adalah tidak faham materi yang diajarkan, rumus-rumus yang kurang dimengerti

P: Bagaimana solusi untuk mengatasi kendala pembelajaran online MAN 2 Langkat?

J: Solusi dari guru mereka melakukan belajar door to door seminggu sekali selama masa covid-19. Dan kami berharap dari pihak sekolah menambah waktu tatap muka lebih banyak

P: Bagaimana kegiatan pembelajaran di MAN 2 Langkat terjadinya pandemik COVID 19?

J: Pembelajaran matematika selama masa covid19 dilakukan secara online atau daring, dan seminggu sekali guru mendatangi kerumah siswa atau door to door

P: Aplikasi apa yang digunakan guru untuk melaksanakan kegiatan pembelajaran online MAN 2 Langkat?

J: Aplikasi yang digunakan selama belajar matematika adalah aplikasi Zoom, Schoology, Edmodo, dan Google Classroom.

P: Bagaimana pelaksanaan pembelajaran online dengan menggunakan aplikasi tersebut di MAN 2 Langkat?

J: Dalam menyampaikan materi pembelajarannya, guru pertama mengirim materi yang akan dipelajari yang harus kami fahami, lalu berdiskusi dan dipersentasikan melalui aplikasi zoom 
P: Bagaimana hasil dari pembelajaran online tersebut di MAN 2 Langkat?

J: Hasil belajar melalui daring tidak maksimal seperti belajar dengan tatap muka

Hasil wawancara siswa dapat disimpulkan pembelajaran online sebagai salah satu jalur penghubung pembelajaran yang belum usai menjadi salah satu solusi di MAN 2 Langkat sebagai pengganti kegiatan pembelajaran tatap muka, meskipun terdapat kendala, pembelajaran masih tetap berjalan dengan baik. Aplikasi yang digunakan untuk pembelajaran online yaitu Zoom, Google Classroom, dan Schoology.

Pembelajaran pada masa pandemi covid-19 dimulai dengan guru memberikan informasi melalui grup Watshap mengenai waktu belajar. Setelah itu guru memberikan materi di grup itu mengenai materi yang akan dilaksanakan, kemudian guru mengarahkan siswa untuk membaca dan memahami materi tersebut. Pembelajaran di lanjutkan dengan menggunakan berbagai aplikasi sepert zoom, Schoology, Edmodo, dan Google Classroom. Di mulai dengan mengabsen siswa, didalam grup guru juga menjelaskan materi yang telah dibagikan kepada siswa. Setelah guru menyampaikan materi tersebut, siswa diaharapkan untuk mengajukan pertanyaan. Setelah itu, guru memberikan soal di geogle classroom untuk dikerjakan dalam waktu satu minggu. Solusi dari guru mereka melakukan belajar door to door seminggu sekali selama masa covid-19. Dan kami berharap dari pihak sekolah menambah waktu tatap muka lebih banyak.

\section{Evaluasi Pembelajaran di MAN 2 Langkat}

Evaluasi pembelajaran pada hakikatnya bukan hanya meniai hasil belajar, tetapi juga prosesproses yang dilalui pendidik dan peserta didik dalam keseluruhan proses pembelajaran. Berdasarkan hasil wawancara peneliti dengan Ibu SJ selaku guru Matematika di MAN 2 Langkat pada hari Jum'at, tanggal 28 Agustus 2020 pukul 09.00 WIB di ruang guru mengenai evaluasi pembelajaran Matematika di MAN 2 Langkat, sebagai berikut:

"Dalam pembelajaran di kelas penilaian atau evaluasi yang saya lakukan meliputi tiga aspek, yaitu kognitif, afektif dan psikomotorik. Untuk bentuk penilaian kognitif saya menggunakan tes harian, tes dua mingguan, tes tengah semester dan tes akhir semester. Sedangkan bentuk penilaian afektif saya beracuan kepada kehadiran siswa, kerajinan, kedisiplinan serta partisipasi pembelajaran. Sedangkan bentuk penilaian psikomotorik saya memberikan tugas individual berupa proyek."

Sedangkan penilaian pada masa covid-19 dalam evaluasi yang dilakukan meliputi dua aspek saja, yaitu kognitif dan afektif. Untuk bentuk penilaian kognitif saya menggunakan tes harian, tes dua mingguan, tes tengah semester dan tes akhir semester. Sedangkan bentuk penilaian afektif saya beracuan kepada kehadiran siswa, kerajinan, kedisiplinan serta partisipasi pembelajaran.

\section{B. Pembahasan}

Pembelajaran online merupakan pembelajaran yang dilaksanakan dengan menggunakan koneksi internet sebagai penghubung terjalinnya komunikasi antara pendidik dan peserta didik tanpa adanya kontak fisik. Pembelajaran online memiliki beberapa kelemahan yaitu penggunaan jaringan internet membutuhkan infrastruktur yang memadai, membutuhkan banyak biaya, komunikasi melalui internet terdapat berbagai kendala/lamban. Disamping itu juga terdapat kelebihan yang meliputi kadar interaksi antara siswa dengan guru, pembelajaran dapat dilakukan dimana dan kapan saja (time and place flexibility), Menjangkau peserta didik (siswa) dalam cakupan yang luas (potential to reach a global audience), dan mempermudah penyempurnaan dan penyimpanan materi pembelajaran (easy updating of content as well as archivable capabilities).

Kegiatan pembelajaran online di MAN 2 Langkat dilaksanakan melalui laman yang sudah disediakan di MAN 2 Langkat yang dirancang oleh BTSI (Biro Teknologi dan Sistem Informasi) yang dinamakan f-learning. F-learning ini sudah digunakan oleh beberapa guru, beberapa guru lainnya memanfaatkan aplikasi yang tersedia di Play Store/App Store yang sering digunakan yaitu Google Classroom, Schoology, Zoom, dan Edmodo. Dari hasil wawancara pembelajaran online di MAN 2 Langkat berjalan dengan baik dan efektif karena dapat menyelesaikan sekolah yang belum terselesaikan dengan kendala secara umum yaitu masalah signal dan kuota siswa. Media yang digunakan dalam pembelajaran online di MAN 2 Langkat yaitu menggunakan aplikasi Zoom, Schoology, Edmodo, dan Google Classroom.

\section{SIMPULAN DAN SARAN}

\section{A. Simpulan}

Berdasarkan hasil penelitian dan pembahasan diperoleh kesimpulan bahwa:

1. Pembelajaran pada masa pandemi covid-19 di MAN 2 Langkat, dimulai dengan Pemberian informasi oleh guru melalui grup Watshapp mengenai waktu belajar siswa. Kemudian guru memberikan materi di grup itu mengenai materi yang akan dilaksanakan, setelah itu guru mengarahkan siswa untuk membaca dan memahami materi tersebut. Pembelajaran di lanjutkan dengan menggunakan berbagai aplikasi seperti zoom, Schoology, Edmodo, dan Google Classroom.

2. Penilaian hasil belajar siswa pada masa covid19 dilakukan meliputi dua aspek saja, yaitu kognitif dan afektif. Untuk bentuk penilaian kognitif menggunakan tes harian, tes dua 
mingguan, tes tengah semester dan tes akhir semester. Sedangkan bentuk penilaian afektif saya beracuan kepada kehadiran siswa, kerajinan, kedisiplinan serta partisipasi pembelajaran.

\section{B. Saran}

Adapun saran yang dapat disampaikan untuk penelitian berikutnya terdapat pada instrumen penilaian hasil belajar yang dapat dikembangkan untuk menilai Psikomotorik peserta didik.

\section{DAFTAR RUJUKAN}

Asmedy. (2021). Perbedaan Hasil Belajar Siswa yang Diajar Menggunakan Model Pembelajaran Soal Terbuka dengan Model Pembelajaran Konvensional. Ainara Journal (Jurnal Penelitian Dan PKM Bidang Ilmu Pendidikan), 2(2), 79-88. Retrieved from http://journal.ainarapress.org/index.php/ainj/a rticle/view/36

Lee, A. (2020). Wuhan novel coronavirus (COVID-19): why global control is challenging? Public Health, January, 19-21. https://doi.org/https://doi.org/10.1016/j.puhe. 2020.02.001a
Luh Devi Herliandry Jurnal Teknologi Pendidikan http://journal.unj.ac.id/unj/index.php/jtp Vol. 22, No. 1, April 2020

Permendikbud Nomor 22 Tahun 2016 Tentang Tujuan Pembelajaran Matematika

Sugiyono. 2016, Metode Penelitian Kuantitatif, Kualitatif, dan R\&D. Bandung: Alfabeta:

Sujono, 2018. Pengajaran Matematika Untuk Sekolah Menengah. Jakarta: Depdikbud.

Undang- Undang No. 20 Tahun 2003 Pasal 3 tentang Sistem Pendidikan Nasional

Wawancara dengan Ibu Suam Julianita, S.Pd selaku guru Matematika kelas VIII pada hari Jum'at tanggal 28 Agustus 2020 pukul 09.00 WIB di ruang guru 